OPEN ACCESS

Edited by:

Nitin Kaushal,

World Wide Fund for Nature, India

Reviewed by:

Marc Peipoch,

Stroud Water Research Center

United States

Marloes L. Mul,

IHE Delft Institute for Water Education,

Netherlands

${ }^{*}$ Correspondence:

Nathalie Richards

nathalie.richards@kcl.ac.uk

Specialty section:

This article was submitted to

Freshwater Science,

a section of the journal

Frontiers in Environmental Science

Received: 01 December 2017

Accepted: 26 October 2018

Published: 14 November 2018

Citation:

Richards N and Syallow D (2018)

Water Resources Users Associations in the Mara Basin, Kenya: Pitfalls and

Opportunities for Community Based

Natural Resources Management.

Front. Environ. Sci. 6:138

doi: 10.3389/fenvs.2018.00138

\section{Water Resources Users Associations in the Mara Basin, Kenya: Pitfalls and Opportunities for Community Based Natural Resources Management}

\author{
Nathalie Richards ${ }^{1 *}$ and Dorothy Syallow ${ }^{2}$ \\ ${ }^{1}$ Geography Department, King's College London, London, United Kingdom, ${ }^{2}$ Department of Environmental Studies and \\ Integrated Natural Resource Management, University of Kabianga, Kericho, Kenya
}

Water Resources Users Associations (WRUAs) in the Mara Basin, Kenya, are community-based natural resources management institutions set-up following the Integrated Water Resources Management framework. They are the most local participatory governance structure currently in place managing the tributaries of the Mara river. WRUAs are the link between environmental services from the river and livelihoods of local communities. Opportunities and pitfalls for the undertaking of their roles are assessed through the analysis of four WRUAs. Recognition of local knowledge, procedural considerations in the setting-up and carrying out of activities, as well as distributional aspects of the WRUA undertakings are evaluated in the paper. The authors argue that typical issues identified in critical community management literature appear in this case study: elite capture, dependency on donor support, lack of meaningful participation, and difficulties for scaling up initiatives. However, WRUAs have positively impacted environmental services in a localized and indirect manner, opening opportunities in terms of awareness, scaling water conservation initiatives, and conflict resolution. Future development of WRUAs can improve environmental flows particularly if a targeted follow-up is maintained by encouraging leadership and monitoring the relationship between donors, elites, and marginalized community members.

Keywords: water resources users associations, community based natural resources management, ecosystem services, Mara Basin Kenya, integrated water resources management, water institutions

\section{INTRODUCTION}

The wide embrace and support for participatory, decentralized, and devolved approaches to natural resource management (Community Based Natural Resources Management) is due to the alternative it provides to traditional top-down centralized approaches; it aims to ensure equitable distribution of benefits emanating from natural resources, and the sustainable development of local communities (see Hulme and Murphree, 1999; Kapoor, 2001; Treisman, 2007; Kumasi et al., 2010). Furthermore, sustainable development objectives (stemming for example from the Agenda 21, and the Bruntland Report) underscore the importance of including stakeholder participation-in particular local people-in all stages of decision making and resource utilization from their local 
environment (Hutton et al., 2005; Mbaiwa, 2005). Governance under decentralized arrangements has been considered conducive to increasing the accountability of organizations at all levels (Crook and Manor, 1998), as well as providing more effective management of natural resources at local levels (Ribot, 2003). Decentralization and participation have often been promoted as means to optimize water efficiency and work toward full cost recovery, although it is still debated how full cost recovery and equitable distribution can both be met (Watson et al., 1999; Smet, 2003; Rap and Wester, 2013; Suhardiman and Giordano, 2014; Rusca et al., 2015). Indeed, a number of challenges such as incomplete transfer of authority to local organizations, lack of transparency and accountability, and usurpation of power by local elite have been reported as negatively affecting the equitable distribution of resources (Ribot, 2002; Shackleton et al., 2002; Hobley, 2005; Zulu, 2009). Local elites are defined as "a small group of well-connected and resourceful individuals who 'exert disproportionate influence over collective action'” (Beard and Phakphian, 2012, p. 150 in Wong, 2013, p. 380). Continued conflict over access and utilization further points to gaps or weaknesses in the set-up of community-based organizations. These discussions prompt an in-depth investigation to identify and comprehend operations of existing community-based organizations, as well as their impact on environmental flows and water users' livelihoods. Environmental flows are also called reserve flows in Kenya, Tanzania, and South Africa, where basic human needs are included, in addition to the needs of aquatic ecosystems. The concept of reserve flows offers a holistic view of aquatic ecosystem services and their allocation for various uses; this is done by recognizing their social aspects, such as providing food, water, medicines, building material, support for grazing, as well as resources for cultural and religious activities (King et al., 2000). This vision goes beyond the instrumental view of water as an economic good. In this paper the term "environmental flows" only is used.

CBNRM is born from neo-liberal agendas and decentralization: responsibility for the sustainability and cost-efficient use of the resource is transferred to users through the crafting of local institutions. New Institutional Economists such as Ostrom (1990) developed a large part of the current thinking on CBNRM, focusing on collective management of ecosystems, to improve human wellbeing whilst empowering locals to manage resources without damaging, depleting or degrading them (Fabricius et al., 2007). It is believed communities will invest in environmental conservation if they can utilize the resources on a sustainable basis for their own benefit, and if it can demonstrate that sustainable natural resource management brings positive economic returns. CBNRM is based on crafting appropriate institutions under which resources can be legitimately managed and exploited by resident communities, for their economic advancementfor instance poverty alleviation and food security-through rational choice. Based on the 8 design principles of Ostrom (1990), World Bank funded studies have established lessons based on projects' best practices to identify the ideal set-up within which CBNRM can take place. These are for example: benefits accruing from the management of a resource should exceed costs; the resource must have a measurable value to the community; those living with the resource should receive higher benefits, and be more involved in the decision making regarding the resource than the larger groups; good practices by communities should always be rewarded, and if the communities do not invest in good management then benefits should fall (Wanje et al., 2017). Participation of local communities in planning, management and decision making is considered an important element in the conservation of natural resources (Stoll-Kleemann and Welp, 2008), although it may take different forms depending on the level of community involvement in resource management, ranging from low to high (Agrawal, 2001). According to Rodríguez-Martínez (2007) and Schultz et al. (2011), involvement could either be through consultation, taking joint decisions, or self-managing natural resources; CBNRM ideally also aims for an integration of indigenous property rights, values, and ecological knowledge in the management of the resource (Kellert et al., 2000). An example for this type of integration is allowing some space to maneuver around the very structured format of management plans: pre-designed formats currently do not allow to ask open ended questions to gather information about new emerging issues, such as planning for the effects of climate change.

In line with the cost-recovery view of managing natural resources, the ecosystem services approach acknowledges that the exploitation of natural resources is a potential driver for economic growth. Overdependence and unregulated exploitation of resources have been a major threat to the continued existence of these resources, and their ability to continue providing environmental resources and services upon which rural communities depend (Reardon and Vosti, 1995; De Groot et al., 2002). Harnessing the benefits local communities obtain from natural resources (ecosystem services) has been proposed as a way to achieve sustainable development and address the cycles of chronic poverty so pervasive in Africa. Ecosystems services (ES) are essential parts of human livelihood and productivity supplies, in that human/environment interactions affect supply and demand of ES (Vrebos et al., 2015). Overuse, misuse, or mismanagement of ES thus occur whenever service demands exceed supply (Wangai et al., 2016). To counter this, CBNRM has been suggested as a panacea to environmental problems, although critical views have shed light on some of the reasons why participative natural resources management has not always been successful in providing ecosystem services in an equitable and cost-efficient way to local communities. The social justice literature discusses these issues by proposing a frameworkdeveloped in the following section-for improving equity in the context of developing local institutions for conservation.

\section{Community Based Natural Resources Management for Water Resources in Kenya}

Kenya has shifted to decentralized control over water resources, despite growing skepticism around the application of Integrated Water Resources Management (IWRM). It has done so by 
applying the IWRM framework and associated Dublin principles, including a participatory approach to water management (Molle, 2008; Allouche, 2016; Manzungu and Derman, 2016). The enactment of the Water Act of 2002, as well as the constitution in 2010 and the recent 2016 Water Act all acknowledge the importance for community participation in the management of resources, resulting in the formation of Water Resources Users Associations (WRUAs) within the six drainage areas of Kenya (Lake Victoria North Basin, Lake Victoria South Basin, Rift Valley Basin, Athi River Basin, Tana River Basin, Ewaso N'giro River Basin). The 2002 act recognizes the roles played by stakeholders in effective water resource management and gives provision for their inclusion in resource management through WRUAs defined as community groups "focused on the management and conservation of water resources of a particular area, river or aquifer" [(The Water Act, 2002): section 15 (3)(e)]. WRUAs key objectives are to promote controlled and legal water use activities; good management practices that make efficient and sustainable use of water resources; the safeguarding of environmental flows for downstream ecological demands and basic human needs; the reduction of water use conflicts; and catchment conservation measures to improve water quantity and quality. In the past 15 years, international donors-under the principles of IWRMhave focused on including community participation in the effort to conserve the Mara River Basin endowed with rich forest, wildlife and water resources. Kenya seeks to preserve environmental flows, meaning domestic use and environmental flows - understood as social goods-take priority over economic water use (e.g., for large scale irrigation).

This paper discusses the roles, pitfalls, and opportunities for WRUAs, as community-based natural resources management (CBNRM) institutions responsible for the safeguarding of environmental flows in the Mara River Basin. The roles and impacts WRUAs have, as community organizations managing water resources for environmental services, are analyzed by using the equity framework developed by Schreckenberg et al. (2016) (see also Franks et al., 2016) and introduced in the paper's framework. Following this, the Mara Basin's context and deriving ecosystem services on which the basin's population depends are discussed. The case study analysis section evaluates opportunities and pitfalls of four Mara basin WRUAs through the framework's lens. Shedding light on the opportunities and pitfalls emerging from the crafting of institutions will hopefully offer insights to water resources managers implementing CBNRM projects. Finally, the discussion brings together the different WRUA assessments, before concluding on the impacts WRUAs have had in regulating ecosystem services from the Mara basin rivers. The paper then suggests actionable recommendations for water resource managers pursing to overcome barriers to CBNRM.

\section{KEY CONSIDERATIONS FOR UNDERSTANDING CBNRM: FRAMEWORK FOR ANALYSIS}

Key characteristics of CBNRM organizations are now discussed using the equity framework suggested by Schreckenberg et al.
(2016) (see also Franks et al., 2016) and drawing from theoretical perspectives and practical examples emerging from critical research. The equity framework discusses enabling processes which empower and allow equitable sharing of benefits, as growing evidence shows that these factors allow for more effective conservation (Oldekop et al., 2015). The framework identifies three interlinked dimensions which necessitate a set of enabling conditions: (a) recognition, (b) procedure, and (c) distribution.

\section{Recognition}

In theory, CBNRM aims to transfer power through participation and recognition of traditional knowledge and customary property rights of marginalized peoples (Gilmour and Fisher, 1991; Little, 1994; Lynch and Alcorn, 1994; Strum, 1994; Sarin, 1995). This means that the disproportionate influence of powerful actors on decision making processes must be counteracted (Schreckenberg et al., 2016). Indeed, in practice, some actors manage to increase their authority through CBNRM mechanisms for their own interests (as found by Kellert et al., 2000 in their study on CBNRM in Nepal, Kenya and the United States, and Jere et al., 2000 in a study of eight CBNRM projects in Malawi): participation was found to be unevenly spread across communities, partly due to corruption and weak leadership. Communities stepping out of pre-designed and approved management plans would undergo intervention by government officials, showing how local ecological knowledge outside modern scientific understanding may be dismissed by powerful actors. In this case, the incorporation of local and modern knowledge appears difficult, as modern scientific understandings are not made more accessible to local people (Kellert et al., 2000). Furthermore, the outcomes of CBNRM are evaluated based on external-as opposed to local-scientifically constructed criteria, revealing a paradox of CBNRM: its aim is to integrate knowledge embedded in specific environmental and social spaces, but evaluated through seemingly objective formalized scientific criteria (Blaikie, 2006). Negotiating a hybrid understanding of knowledge is subject to relationships of power between the outsiders and insiders to the CBNRM projects (Batterbury et al., 1997).

\section{Procedure}

Procedural equity consists in insuring that participation is inclusive of all actors, and effective. The values of communities should be respected, and traditional decision making institutions must be strengthened (Schreckenberg et al., 2016). Under CBNRM, conflict resolution takes place through mechanisms starting from local to national authorities (Kellert et al., 2000).

Due to centralized government's minimal human and financial capacity for monitoring open access resources, CBNRM is believed to offer an alternative, by handing over the policing role to local residents-who are additionally aware of de jure and de facto tenurial arrangements for the access of shared resources (Blaikie, 2006). However, Kellert et al. (2000) found that although CBNRM allowed for new platforms to discuss and resolve conflicts, conflicts increased overall because of the higher expectations new management mechanisms created. In addition, 
the creation of new pre-designed organizations also created institutional overlap, as well as opportunities for rent-seeking from local elites (Blaikie, 2006).

\section{Distribution}

In order to encourage conservation practices, CBNRM also aims to improve social and economic standards of local and rural peoples (Wells and Brandon, 1992), particularly through a more equal distribution and allocation of resources (Kellert et al., 2000). However, it also often comprises costs associated with conservation, for example the exclusion of livelihood activities from certain areas (which sometimes entails the distribution of compensation). Debates persist on whether compensation should be divided equally or whether those most affected should receive targeted compensation (Schreckenberg et al., 2016). In their study on CBNRM in Nepal, Kenya, and the United States, Kellert et al. (2000) found that the distribution of material and political benefits from resources, as well as the devolution of decision making powers, benefited more certain groups of people (e.g., those living closer to the center of CBNRM headquarters, or board members). Shackleton et al. (2002) conclude from 13 case studies across Africa that although the overall benefits of CBNRM vary widely, the negative trade-offs generally fall onto the poor. In another study of eight African countries, Shackleton and Campbell (2001) argue that when the state limits its involvement in the shaping of CBNRM, communities are better able to shape the social-environmental relationship to their advantage.

Since CBNRM aims to conciliate conservation goals through economic and social incentives (Kellert et al., 2000), it tackles both rural poverty and biological diversity (Parker, 1997; Butler, 1998; Mehta and Kellert, 1998; Wainwright and Wehrmeyer, 1998). In the context of water resources, this entails providing better ecosystem services for the poor, including improved water in terms of quantity and quality, with minimal tradeoffs. CBNRM suggests the setting-up of local institutions, acting as regulators and platforms to negotiate the practicalities of harnessing conservation, and economic and social welfare.

Studies have however shown how some of the newly established institutions for CBNRM in developing countries switched their focus toward community development activities to pursue social and economic advancement, rather than focusing on the protection of biodiversity (Kellert et al., 2000). In other cases however, expatriate workers involved in the implementation of CBNRM have admitted that the programme aims are conservation and that the community developmental aspect is worked on in order to achieve the aim of conservation (Taylor, 2001). In this case, the pro-poor component of CBNRM is arguably retro-fitted in order to legitimize certain funding streams (Blaikie, 2006). It is thus questionable whether conservation goals can truly be coupled with economic and social development, or whether the CBNRM form through which these two goals are advocated is ill designed. In the particular case of Kenya, the lack of environmental and socio-economic data meant that the idea of a sustainable equilibrium point between conservation and usage was impossible to determine, and therefore implement (Kellert et al., 2000).

\section{Enabling Conditions}

The equity framework-based on recognition, procedure and distribution-rests on the idea that there are enabling conditions which are beyond the control of stakeholders, which may allow for greater equity within CBNRM initiatives. These are the presence of adaptive learning approaches, aligned statutory, and customary laws and norms, and finally awareness and capacity from the actors to achieve recognition and participate effectively (Schreckenberg et al., 2016, p. 15). The participatory aspect of CBNRM heavily rests upon the concept of community, the term itself holding a certain number of assumptions: it can be understood as a spatial unit, a social structure or a set of norms which are shared with a group of people (Agrawal and Gibson, 2001). The overlap of these criteria with the nature and scale of the resource being managed does not always correspond (Blaikie, 2006). Moreover, participatory approaches to natural resources management assume that the community is somehow a homogeneous unit, forgetting the complex web of social arrangements and decision making. Equally, there is a certain optimism about the benefits of participation, forgetting that it also has a cost (Cleaver, 1999). Overall, participatory approaches to development encounter great success because they are believed to bring monetary efficiency and effectiveness, at the same time as bringing empowerment and democratization (Cleaver, 1999). However, empowerment as an outcome is difficult to measure, although it entails the influence of participants over project frameworks (Eyburn and Ladbury, 1995; Cleaver and Kaare, 1998; Cleaver, 1999), including the recognition of other forms of science. Lastly, critical views question who is to be empowered: if communities are the most appropriate unit for governing natural resources, then how is external intervention justified? (Cleaver, 1999; Blaikie, 2006).

\section{METHODOLOGICAL CONCERNS: LINKING INSTITUTIONAL AND ECOSYSTEM SERVICES OUTCOMES}

The Mara basin case study provides grounds to discuss recognition, procedure, distribution, and enabling conditions for the Water Resources Users Association to govern the environmental flows of the tributaries of the Mara basin. Environmental flows are a direct and measurable outcome of the effectiveness of the setting-up of new governance systems, such as the inclusion of CBNRM initiatives. The Mara river is a case in point as it provides for numerous livelihood activities which depend upon its ecosystem services (themselves dependent on sustained environmental flows), as well as renowned national parks. The IWRM framework from which WRUAs stem, as well as the environmental justice literature concerned with social equity recognizes the need to combine ecosystem health with equitable sharing of water resources (Savenije and Van der Zaag, 2008). The Brisbane Declaration (2007) defines environmental flows as "the quantity, timing, and quality of water required to sustain freshwater and estuarine ecosystems and the human livelihoods and well-being that depend on these ecosystems." In this sense, there is a strong link between access to healthy 
resources, and a healthy life through sustainable livelihoods supported by water resources. Ecosystem services are thus the connection between the socio-economic system and the ecological system (Boerema et al., 2016). The idea of durably securing environmental flows has emerged as a key concept, with the role of maintaining healthy river basins amidst competing water demands (Tharme, 2003). Environmental flows and the ecosystem services derived from them are thus key indicators of the effectiveness of WRUAs. To date, the government of Kenya is looking into making a final determination to establish what the value of environmental flows should be (in this case valuing a minimum flow to cover basic human needs and environmental needs). At the moment, the environmental flows must be a value not $<$ Q95 (Q95 represents a magnitude of flow that is exceeded $95 \%$ of the time in the river, meaning that depending on the flow variability of the river, the percentage of the flow for Q95 can cover a range of values).

This paper presents research conducted over 8 yearsbetween 2009 and 2017-with local WRUAs in the Mara basin, responsible for preserving ecosystem services stemming from environmental flows. The study covers qualitative data from the set-up to the follow-up of WRUAs' daily activities within the basin. Qualitative research has been conducted through participative observation, interviews, surveys and monitoring tools to investigate the impact of WRUAs over environmental flows and livelihoods of local people engaged and disengaged from WRUAs activities. Four WRUAs have been selected based on time of existence and location (upper and lower tributaries of the Mara have been chosen). Amala and Isei WRUAs have been in existence for over 5 years (stemming from Mara WRUA which started in 2003), whereas Naikarra and Leshuta WRUAs were constituted $<5$ years ago. Amala and Isei WRUAs are located on the upper tributaries of the Mara River Basin, as opposed to Naikarra and Leshuta WRUAs, which cover downstream tributaries of the Mara. These WRUAs furthermore make interesting case studies for the application of current policy, as Amala and Isei WRUAs, and Leshuta and Naikarra WRUAs used to be united prior to the regulation stipulating a maximum coverage of $150-200 \mathrm{~km}^{2}$ per WRUA. All qualitative data was transcribed and coded inductively and deductively, sorting key information through the equity framework developed in the previous section. The data was classified according to the three identified interlinked dimensions of recognition, procedure and distribution, alongside a set of enabling conditions. Key indicators and factors for opportunities and challenges stemming from these dimensions are discussed in the following sections, in link with the role of WRUAs for ecosystem services preservation.

\section{POLICY AND IMPLEMENTATION ASSESSMENT: CASE STUDY OF WRUAS IN THE MARA RIVER BASIN}

The Mara basin (see Figure 1) covers an area of $13,750 \mathrm{~km}^{2}$, taking its source in Kenya in the Mau Escarpment, traveling through the Maasai Mara and Serengeti national parks and finding its outlet in Lake Victoria, Tanzania (Mango et al.,
2010). Six sub catchments form part of the Mara basin on the Kenyan side: these are Nyangores, Amala, upper Mara, Engare Ngobit, Talek, and Sand. The Amala and Nyangores rivers are perennial, whilst the Talek, Sand and Engare Ngobit only contribute seasonally (Mati et al., 2008). Rainfall occurs between 1,000 and $1,750 \mathrm{~mm}$ per year in the source area at an altitude of around $2,932 \mathrm{~m}$. The amount of rainfall decreases to $300-$ $1,000 \mathrm{~mm}$ per year at the middle and outlet areas situated at an altitude of around 1,134 m (Dessu and Melesse, 2012). Small scale crop farming is the dominant land use within this zone, whereas lower parts of the basin with an annual rainfall of 500-700 mm supports activities such as irrigated agriculture, livestock rearing and wildlife conservation.

In recent years, the Mara basin has experienced land use changes, with increases in population (the 2009 census estimated the Kenyan population within the Mara at around 590,000; Kenya National Bureau of Statistics, 2010), increased forest and savannah grassland clearance for grazing, expansion of large scale irrigation, tourism, and mining (Hoffman et al., 2011). These changes have given rise to peak flows, and reduced low flows (Mati et al., 2008). Kenya's water law (Republic of Kenya, 2007) recognizes the need to secure environmental flows, prioritizing environmental flows, and access to domestic water over any other abstraction for economic purposes. Environmental flows are sustained as long as the reduction in quantity of quality of the flow is not jeopardizing freshwater ecosystems dependent on them. The organisms governing water quantity and quality influencers therefore deserve close scrutiny. Under Kenyan Law (Republic of Kenya, 2007) management and use of water resources are regulated by the Water Resources Authority (WRA), and WRUAs are involved as grassroot managers. The following responsibilities are the main roles of WRA:

- Planning, management, protection, and conservation of water resources

- Allocation, apportionment, assessment, and monitoring of water resources

- Issuance of water permits

- Water rights and enforcement of permit conditions

- Regulation of conservation and abstraction structures

- Catchment and water quality management

- Regulation and control of water use

- Coordination of the IWRM Plan;

whereas WRUAs hold the following roles:

- Involvement in decision making process to identify and register water user

- Collaboration in water allocation and catchment management

- Assisting in water monitoring and information gathering

- Conflict resolution and co-operative management of water resources

IWRM plans are developed at the sub catchment level through sub catchment management plans. The operations and activities of WRUAs are in line with the IWRM and sub catchment management plans. The catchment management plans have been developed to date, and constituted WRUAs have their individual sub catchment management plans; these are prepared during the 


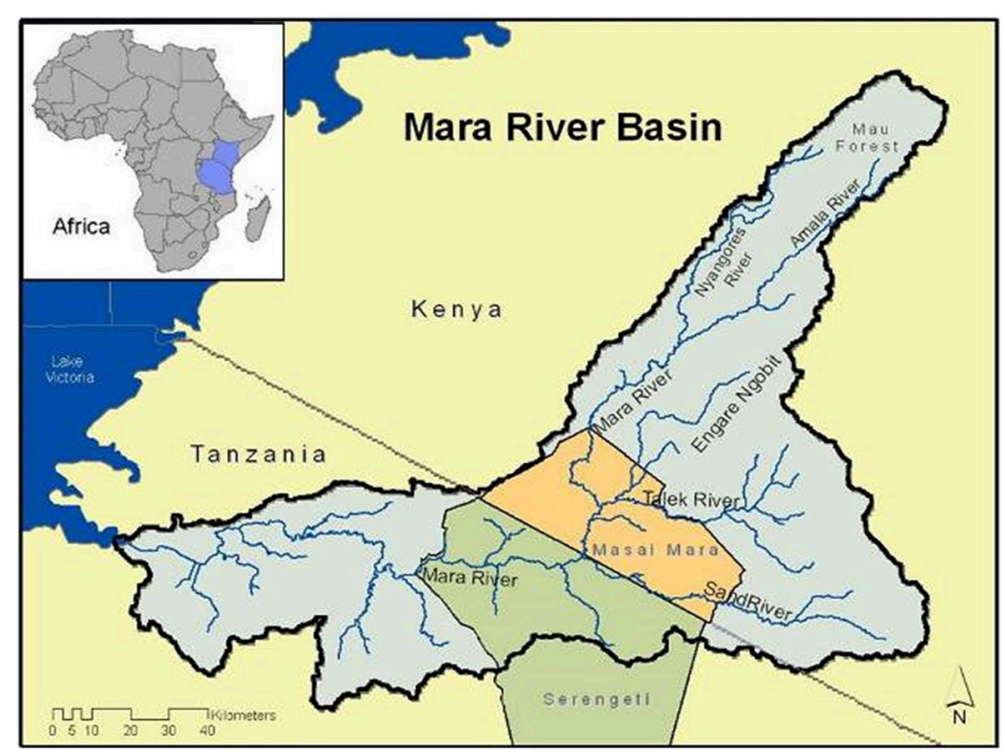

FIGURE 1 | Map of the Mara River Basin (Reza, 2013).

formation phase of the WRUAs. The Water Act (2002) (section 15) and Water Act 2016 anchor these plans at various levels. Concerning the monitoring of environmental flows, it is key to note that this task is not yet in the hands of WRUAs.

There is a significant difference in river usage between the upper stream tributaries (Amala, Nyangores, and upper Mara) and the downstream tributaries (Ngare Ngobit, Sand, and Talek), meaning that a wide range of ecosystem services are being used along the entirety of the river. This also means that WRUAs focus on different aspects of ecosystem management and provision. Services which cover all areas are the following: water abstracted for basic human needs (drinking, cooking, and sanitation); ecosystem services deriving directly and indirectly from environmental flows: fish, wild fruit, medicinal plants, as well as organic and inorganic material (for firewood, building); water for productive livelihoods, such as livestock watering and irrigated cultivation (this categorization follows the reserve quality standards in reference to the environmental flows assessment as stipulated by Kenyan Water laws; Republic of Kenya, 2007) (Wambugu, 2017). Overall, the main economic activity is small scale agriculture, followed by livestock keeping, as well as tourism in the national parks (Hoffman, 2007). The lower reach catchments are mostly populated by Maasai who are nomadic pastoralists, whereas the upper catchments are mostly populated by Kalenjin who practice small-scale agriculture. Water-related activities can be divided between those which are included in the water permitting system and those which constitute the environmental flows (water usage for basic needs without infrastructure such as cattle troughs or improved irrigation intakes, and water for ecological use). Wambugu (2017) shows that a large majority of households depend on the Mara tributaries for fulfilling basic human needs. The lower sub catchments_in particular Talek - are highly dependent on the river for their livestock subsistence (with little other livelihood activity as the rainfall is too low for agriculture), whereas the upper catchments depend on the river for cultivation during planting and dry seasons, as well as fishing activities. Given the high dependence of all dwellers of the Mara basin on the rivers, managing and distributing resources between upstream and downstream communities is of high importance.

The IWRM framework advocates the management of water resources from the lowest to the highest levels of governance, with the lowest organizational level being WRUAs. For a WRUA to be formally recognized it must be registered as an Association with the Attorney General under the Societies Act as well as enter into a Memorandum of Association with the WRA. Between 2003 and 2008 there was only one WRUA (Mara WRUA) covering the entire basin. The size of the WRUA was however unable to cope with the following challenges: firstly, the vastness of the basin presented logistical challenges to bring together members; secondly, diverse ecological characterization of the basin created problems, as the upper and mid catchment experienced totally different issues from pastoralists in the lower catchments. Hence the platform under Mara WRUA did not address these challenges effectively. In 2009, with the support of different development partners [including World Wildlife Fund (WWF)] and in collaboration with the WRA, the WRUAs were reorganized along the major tributaries of Nyangores, Amala, Lower Mara, Talek, and Sand river (see the six sub catchments illustrated in Figure 1 on the Kenyan side of the basin). In 2010, an amendment of the Water Act of 2007 provided a clear direction on the coverage area of a sub catchment, resulting into the disintegration of the 6 existing WRUAs into 25 smaller units to conform to the water regulation (see Figure 2 representing the 25 planned WRUAs, excluding the Mara WRUA which currently only serves as a platform). There are 25 planned WRUAs in total, 


\section{MARA RIVER BASIN WRUA'S}

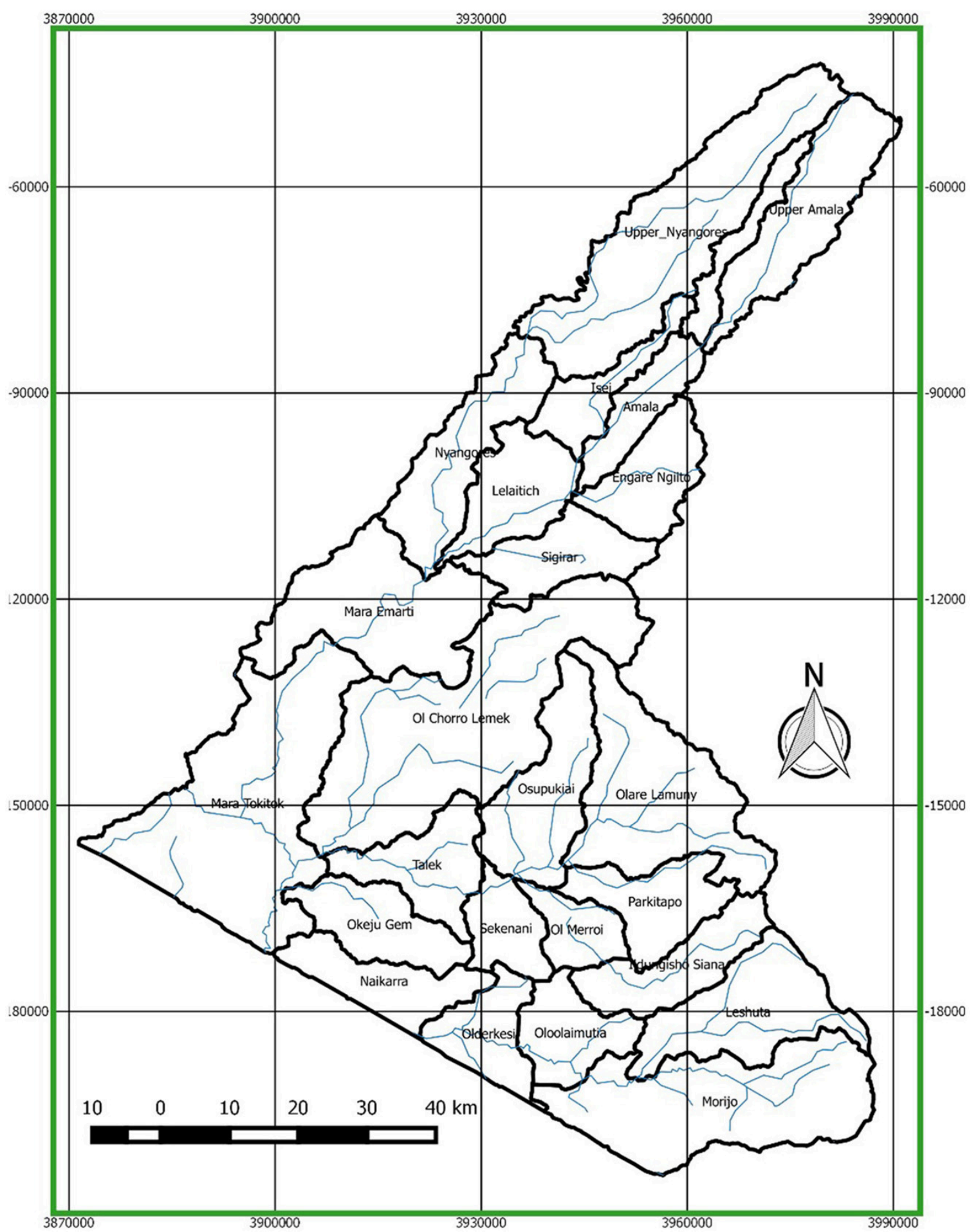

FIGURE 2 | Mara River Basin WRUAs (GIZ, 2018). 
with only 19 fully constituted; the WRUAs are spread across the basin, each one of them covering between 200 and $250 \mathrm{~km}^{2}$ as per the 2007 Water Act (see Figure 2).

The WRUAs sub catchment management plans (SCMPs) outline the conservation and catchment restoration duties of the WRUAs as such:

i. Controlling abstractions by monitoring and identifying legal and illegal abstractors

ii. Pollution control through monitoring the dumping of waste into rivers and streams

iii. Improving farming and land management practices to reduce soil erosion and to improve agricultural productivity

iv. Protecting riparian zones to reduce sedimentation in the river

v. Improving access to clean water by protecting springs.

The making and final production of SCMPs vary slightly from WRUA to WRUA, however professionals from the WRA and funding NGOs follow a standardized procedure and template, resulting in similar SCMPs across all of the basin.

Four categories of WRUA membership exist:

1. Riparian land owners (either individual or community group)

2. Abstractors who directly draw water from water points such as rivers or springs (e.g., schools, hospitals, and churches)

3. Commercial and industrial businesses

4. Ex-officio members such as relevant government departments and non-governmental organizations operating within the sub catchments.

One becomes a bonafide member upon payment of a membership fee and an annual subscription, which varies across the different categories (from KSH 100 to KSH 2,000).

This paper chooses to present the assessment of four WRUAs, representing up, mid and downstream cases, covering a variety of ecological and livelihood contexts within the Mara basin. The aim is to discuss the WRUAs within the equity framework to evaluate the impact the creation and rolling out of WRUA activities may have had on ecosystem services provided by the river, as well as livelihoods. WRUAs are first introduced, and Table $\mathbf{1}$ assesses them in light of the equity framework.

\section{Amala WRUA}

The Mara River basin initially only had one WRUA (Mara WRUA-now unofficially an overarching organization for WRUAs), which was subsequently officially divided into smaller units to cope with the scale of the basin and the efficiency of the tasks undertaken by the WRUA. Amala was therefore born out of the Mara WRUA in 2009, with the prerogative of operating within the Amala sub catchment. Members within a self-help group started the WRUA and in 2012 it evolved to attain status of an association through registration under the Societies Act, with the support of WWF. Today, Amala WRUA also counts village chiefs within its WRUA members. Amala WRUA holds its office with the overarching Mara WRUA, and together they sustain a tree nursery and keep records of basic river measurements. Amala WRUA's activity is mostly to protect riparian zones by replacing farming with productive trees such as mango, avocado and banana trees. Donor-led activities have also been implemented in line with its SCMP, for example through bee keeping training, and the donation of dairy cows and sheep to provide for alternative livelihoods in order to move away from unsustainable agricultural practices affecting environmental flows.

\section{Leshuta WRUA}

Leshuta WRUA covers the lower parts of the Mara River Basin, having evolved from the larger Naikaraa WRUA (which covers the Sand River) after the enactment of water regulations slicing coverage areas of WRUAs. Leshuta WRUA was registered in 2012 after experiencing water scarcity due to its location in a semi-arid region. A community meeting was convened with the help of members who had already subscribed to the larger Sand River WRUA and came from the Leshuta zone. The purpose was sensitizing the community about water resource problems and different ways of managing and conserving under the stewardship of a WRUA. Both outside and local knowledge were considered to shape the WRUA's objectives and priority areas of action. As with other WRUAs, members first register as a self-help group [or community-based organization (CBO)], where a minimum of 30 members is required. Initiatives have shaped in theory but not effectively in practice for the following: protection of water spring to reduce chances of pollution and improve accessibility by locals; identification of suitable sites for locating water tanks for harvesting and storage of water; identification of water pans that have been constructed and rehabilitated; rehabilitation of degraded sites through tree planting and establishment of tree nurseries; monitoring and reporting incidences of illegal tree felling (cedar) to relevant authorities; supporting local member learning centers through equipping them.

\section{Isei WRUA}

Isei WRUA is unique within the Mara River Basin, as it broke off from the main Amala WRUA before introduction of water rules specifying WRUA coverage area. Isei displays particularly good initiative as it has strong leadership from a retired hotelier who is aware and passionate about environmental conservation. The establishment of Isei WRUA started as a table banking system between 15 members who had agreed upon some principles such as land planning in farms, terracing, tree planting, and conservation of spring areas as they are the main source of water. In addition to these practices, the WRUA agreed that every member should grow 500 self-funded tea tree seedlings to add a livelihood component to the WRUA. There is a strong livelihood component to this WRUA: it has managed to link environmental protection with income generation.

\section{Naikarra Sand River WRUA}

The donor (WWF) was behind the constitution of Naikarra WRUA, situated on the Sand river, in the lower reaches of the Mara river in Kenya. Local communities were sensitized about the roles of a WRUA with regard to water resources conservation. Interim officials were elected at the awareness meeting, and they themselves further steered the recruitment of members from different parts of the catchment. Initiatives for environmental 


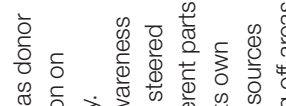

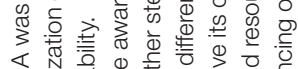

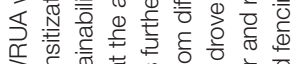

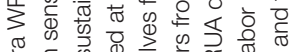

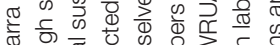

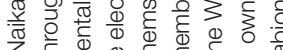

$\sum_{4}$

\ $\quad$ ठ

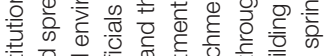

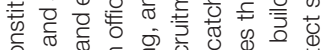

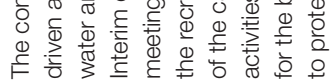

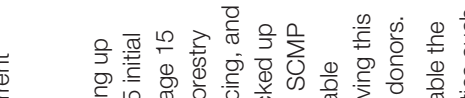

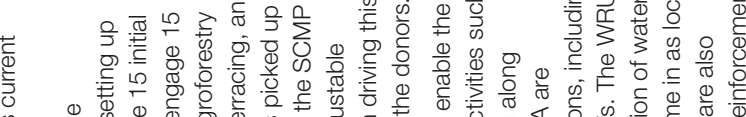
की

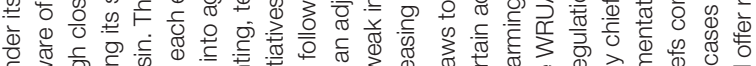

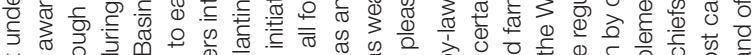

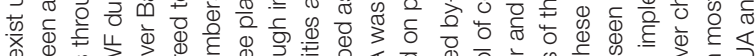

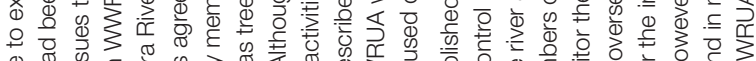

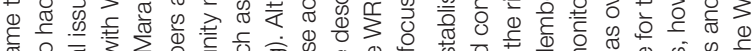

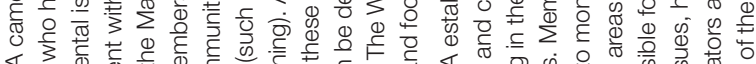

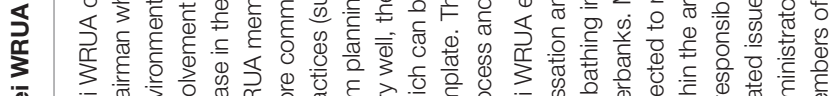

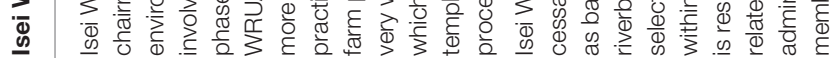

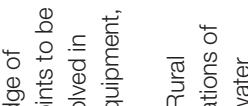

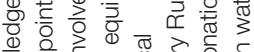

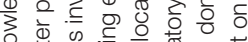

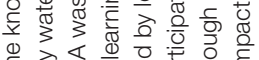

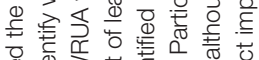

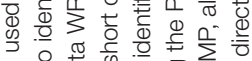

की

荈

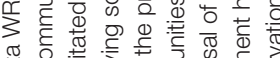

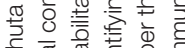

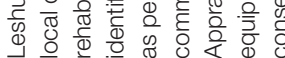

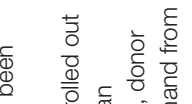

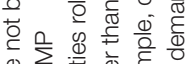

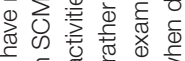

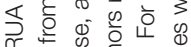

$\stackrel{\substack{5 \\ ⿱ 亠 从 十}}{\frac{01}{3}}$

焉

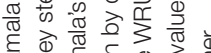

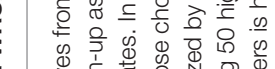

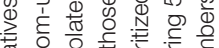

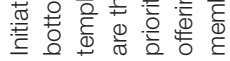

?ते

항

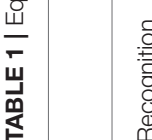

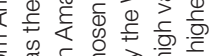

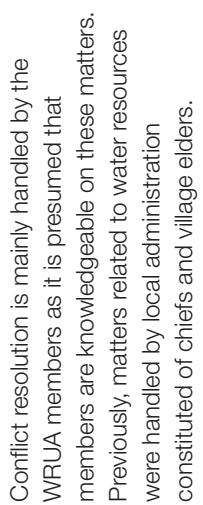

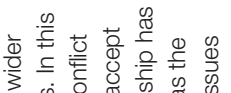

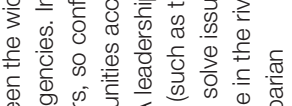

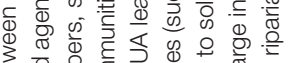

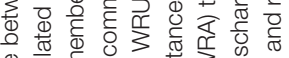

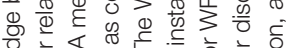

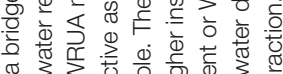

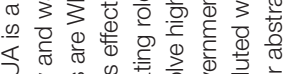

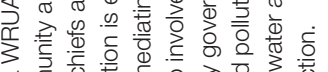

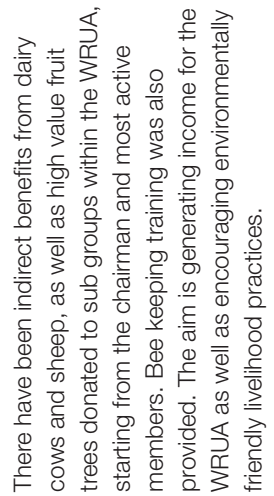

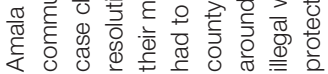

宸

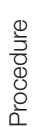

을

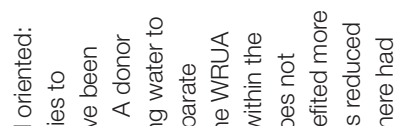

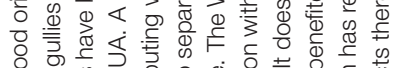

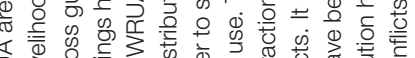

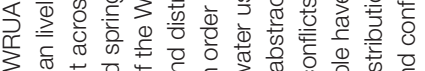

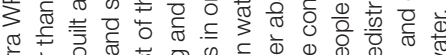

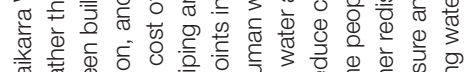

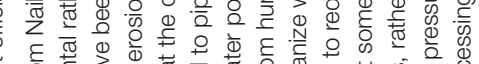

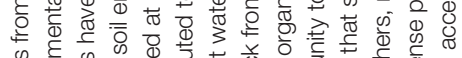

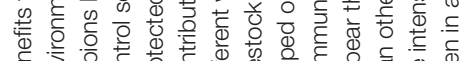

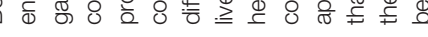

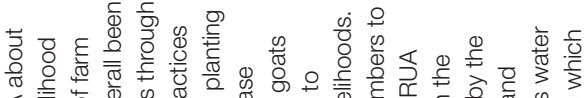

支竞

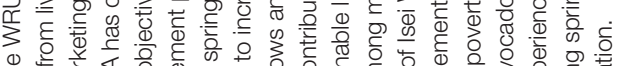
ब

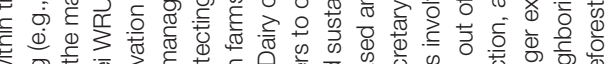

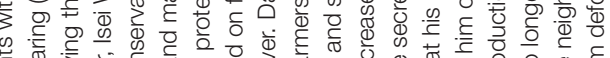

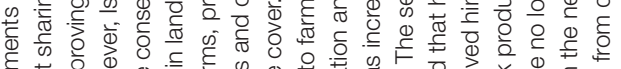

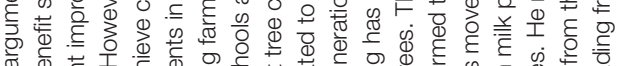

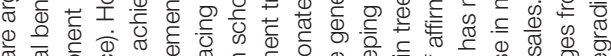

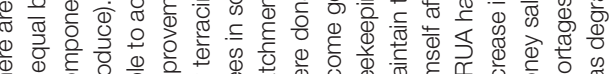

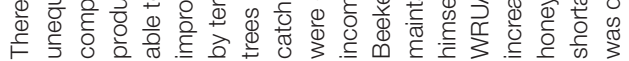

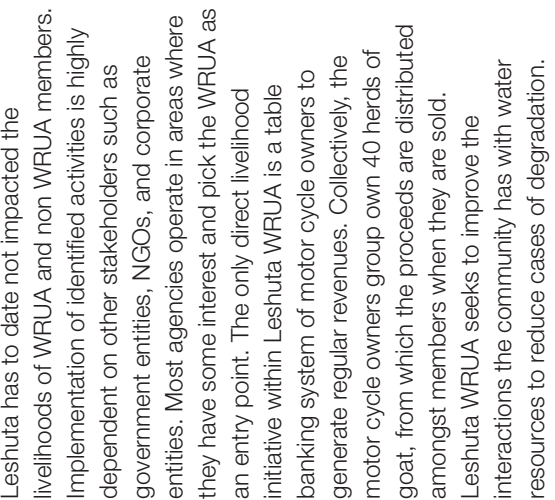

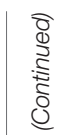




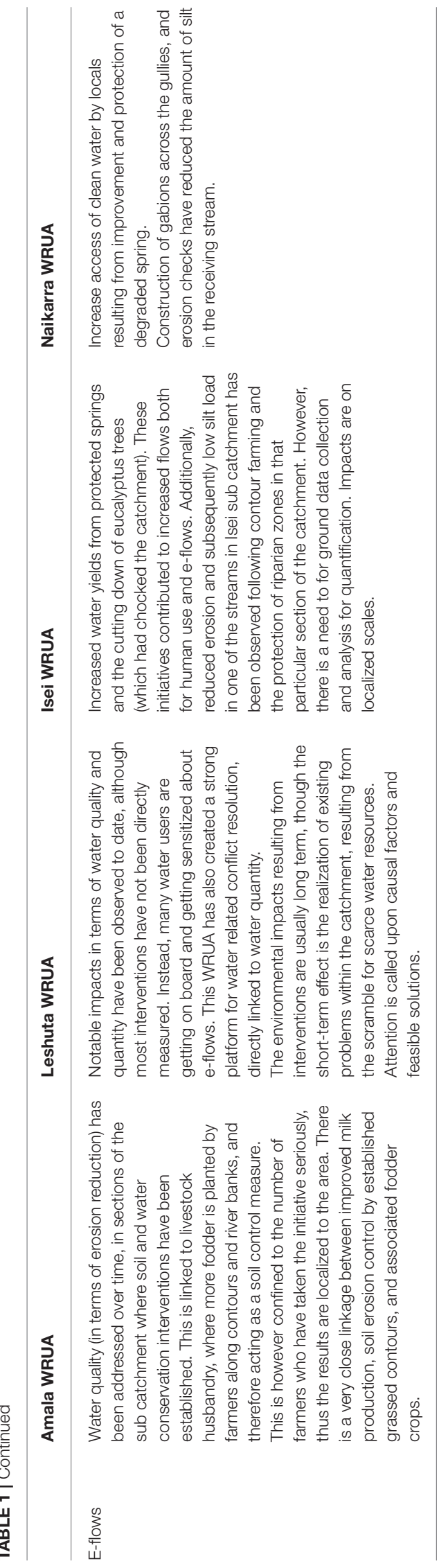

protection have been undertaken with the WRUA members' own resources, although livelihood components to sustain the work efforts are lacking.

The following Table 1 provides the equity analysis of the four Mara WRUAs presented above. Recognitional, procedural, and distributional criteria are evaluated for each WRUA in detail. The discussion then consolidates learnings from the case studies to evaluate these CBRNM organizations and assess the pitfalls and opportunities for their impact on environmental flows.

\section{DISCUSSION: OVERALL IMPACT OF WRUAS ON REGULATING ECOSYSTEM SERVICES}

Regarding recognition, conservation objectives are set by the national government and partnering donor agencies. However, local ecological knowledge is also used, for instance to identify which trees to plant along riparian zones for water preservation, according to localized environmental specificities. Unless the leadership of the WRUA is very active in terms of networking and implementation of activities, the WRUA is often dependent on donors for undertaking activities: this implies that donor objectives come before community objectives. This may occur even when the donor is selecting which activity to fund from the SCMP. In some cases, members of the WRUAs have been part of previous independent CBOs with links to water; nonetheless, WRUAs can barely be qualified as developed from grassroots. Roles in terms of improving water quality of the river for domestic distribution through small towns remain similar between original CBOs and WRUAs, however the structure in which WRUAs are set-up and the constitutions which they hold, as well as the SCMPs they develop, all follow procedures set at the national level by the ministry of water, and implemented through regional WRAs. Templates guide the general role as well as specific activities and tasks. Furthermore, it is questionable how WRUAs may be CBOS whilst being accountable upwards to the WRA at the same time as downwards to the community. WRUAs respect local riverbank ownership rights, whilst sensitizing farmers to better land management practices, to avoid negatively affecting water resources. This sensitization does not go against ancestral local practices: in fact, restoration practices advocated by WRUAs were practiced by past generations and have been abandoned by current generations, trying to reduce costs of production through unsustainable management practices. Sustainability and motivation to undertake activities will only be possible if communities can decide on priorities, rather than follow pre-designed templates. Awareness on linkages between livelihoods and impacts on water resources is however needed.

Procedurally, WRUAs play a significant role in solving conflicts. In the case of river pollution, the WRUAs have reduced bathing and washing in rivers, as well as spraying livestock next to water bodies. They are also increasing the accountability of water users by enforcing rules which have been ignored by newer generations, such as farming along riparian zones (which are protected), and abstracting water illegally. Better management practices are not reported to impact 
livelihoods negatively, as there are alternative measures farmers are able to explore, since riparian farming is forbidden. If illegal abstractors assess abstraction of water for irrigation purposes as their source of livelihood, they can apply for permits for abstracting water for irrigation, and these permits give directions to ensure sustainability measures. WRUAs have improved access to solving water related conflicts, as they are a visible channel for communities where the WRA is less visible. WRUAs are present on the ground on a daily basis, and are therefore available at all times for water related issues. In the case of raw sewage dumping by tourist facilities, the National Environmental Management Agency and the WRA were unaware and unable to act quickly on the issue due to their physical distance; whereas the local WRUA witnessed and started a procedure in due time. WRUAs are the WRA's eyes on the ground: they are able to whistle blow illegal water abstraction and cattle dipping (application of acaride). Transparency in the conflict resolution process depends on the WRUA and cases, however it is very clear that they are perceived as a bridge between local communities and higher authorities: their presence at grassroot level is known, especially for those with active leaders. The inclusion of traditional authorities such as chiefs is key for buy-in, although it may signify elite capture. To avoid this, awareness and inclusiveness must be well spread across the community.

In terms of distribution of benefits, elite capture is very much discernible in most WRUAs, whereby a few specific members have been benefitting from the training and materials donated (often the most active members of the WRUA). This is emphasized when the leadership of the WRUA is nominated, and decides who can benefit from training and resources from donors (for example in the case of Naikarra and Amala WRUAs). The upstream WRUA of Amala has undertaken activities which could produce a real increase in revenue for those who have been part of activities (such as high value tree planting for soil conservation). It is therefore key to understand who has or has not been able to benefit from this initiative. Downstream WRUAs dependant on lower tributaries (Talek and Sand rivers) such as Leshuta and Naikarra are less engaged in crop farming but their livelihoods are highly dependent on water access for livestock. To date it is however difficult to assess the impacts of the downstream WRUAs on livelihoods. Elite capture may be a necessary process to have community buy-in and support from authoritative figures, however special attention and close follow-up must be ensured to avoid further marginalization of less powerful members. Water related activities could potentially provide a new opportunity to marginalized people to gain authoritative leverage within the community.

In order to enable equitable distribution of the benefits of community-based water resources management, awareness of environmental issues linked to water processes must be widely spread. Without this realization, community mobilization, and motivation are extremely difficult. Low awareness generates disbelief in the potential benefits to gain from conserving water resources, and environmentally harming livelihoods activities are continued, albeit being illegal. Despite the low registration and annual subscription fees (starting from KSH 100), community members fail to participate due to the lack of visible results from being part of the WRUA. In Amala WRUA for example, only 100 out of 600 members decided to renew their subscription to the WRUA: slow returns coming from initiatives implemented under the WRUA are the main cause. Overall, linkages between up and down stream WRUAs are weak, thereby diminishing opportunities for WRUAs to have a real impact on improving environmental flows and ecosystem services. Up and down stream WRUAs over the entire basin are covered by the unofficial Mara umbrella WRUA (which acts as a platform for WRUA communication with the Mara basin as a whole, and will soon be transferred to the status of Mara forum for official recognition); however, planned quarterly meetings and annual general meetings rarely occur due to lack of funds. A major pitfall for Mara basin WRUAs are the lack of up/down stream relations at a tributary scale, within sub-catchments.

Since the methodology and results for valuating environmental flows has not yet been determined in the basin, a measured evaluation of the impact of WRUAs on environmental flows is extremely difficult to undertake. This requires more in-depth studies and is an area for further research.

\section{CONCLUSIONS AND RECOMMENDATIONS}

The impact WRUAs have over environmental flows and livelihoods of local communities within the Mara basin must be thought about in indirect and localized terms, as opposed to generalized to the catchment. The hydrological and land use data available is too coarse to establish a link between localized WRUA conservation interventions, and direct impact on environmental flows, downstream livelihoods and national parks. This is why the term environmental flows is used here to evaluate the effects of WRUAs on ecosystem services that stem from the provision of environmental flows. The WRUA SCMPs clearly show the links between environmental flows and livelihoods, as conservation activities impact both. WRUAs therefore have a role in balancing initiatives which may positively impact the ecosystem, but negatively impact livelihoods in the short term, and vice versa. They can also identify and potentially balance benefiters and losers of environmental initiatives.

WRUAs have had the effect of improving the conservation of water resources at localized scales by encouraging environmentally sustainable livelihood practices. Springs have been protected, assuring continuous flow of water and prevention of incidences such as the drying up of both springs and streams. However, silt load reduction in rivers adjacent to farms which have on farm soil conservation structures encouraged by WRUAs arguably does not significantly change the scenario on a catchment scale, with only few farmers taking up these practices. Although some large-scale irrigators are involved in improving the sustainability of the river basin (one in particular who initiated the Mara WRUA very early on), many other large-scale water users are not involved in WRUAs. The process of requesting and building water resources management plans is generally not bottom-up, but donor led. Thus, the types of impacts WRUAs have 
depend on whether the donor is environmentally or socially embedded, as WRUAs have become entry points for donors to channel their programmes. WRUAs therefore tend to be cross-sectorial: more so when they were set-up starting from pre-existing $\mathrm{CBOs}$ already undergoing a range of activities. The intensity of involvement in the WRUAs is rewarded by access to resources; however, this may mean that poorer households unable to offer labor or time do not have access to rewards, leading to weak implementation of the SCMPs. The inclusion of traditional conflict resolution mechanisms generates effective outcomes, as communities refer to their known leaders-higher authorities are only referred to when this process fails. Although it allows for elite capture, the legitimacy required by leaders to convince action from community members may only be available from pre-existing structures. Assessing the impacts of WRUAs in the Mara basin reflects the difficulties in measuring environmental impacts of CBNRM institutions. The web of linkages between environmental services and livelihoods is complex, when set in different scales, landscapes, and stages of institutional development. The question of distribution is key to evaluating desired outcomes: it is crucial to justify who the difficultly measurable outcomes are for, and through which processes they will be implemented.

The following recommendations result from these conclusions:

- Integration of local knowledge and priorities. SCMPs are not shaped entirely bottom-up; participatory methods to engage with environmental flows need to allow sufficient space for finding localized and overlapping solutions for livelihood and environmental objectives, both in the short and long term.

- Procedural transparency. There is a need for procedural transparency in the setting-up and daily rolling-out of CBNRM activities, to enable stronger accountability. The policy and implementation furthermore need to clarify

\section{REFERENCES}

Agrawal, A. (2001). Common property organizations and sustainable governance of resources. World Dev. 29, 1649-1672. doi: 10.1016/S0305-750X(01)0] 0063-8

Agrawal, A., and Gibson, C. (2001). Communities and the Environment: Ethnicity, Gender, and the State in Community-Based Conservation. New Brunswick: Rutgers University Press.

Allouche, J. (2016). The birth and spread of IWRM - A case study of global policy diffusion and translation. Water Altern. 9, $412-433$.

Batterbury, S., Forsyth, T., and Thompson, K. (1997). Environmental transformation in developing coun- tries: hybrid knowledge and democratic policy. Geogr. J. 163, 126-132.

Beard, V., and Phakphian, S. (2012). "Community-based planning in Thailand. Social capital, collective action and elite capture," in The Dynamics of Social Capital and Civic Engagement in Asia, eds A. Daniere and H. Luong (London: Routledge).

Blaikie, P. (2006). Is small really beautiful? Community-based natural resource management in Malawi and Botswana. World Dev. 34, 1942-1957. doi: 10.1016/j.worlddev.2005.11.023 whether WRUAs are accountable downwards to local communities or upwards to the WRA.

- Compensation mechanisms. In the short term, some conservation activities carried out by the WRUAs negatively impact precarious livelihoods; WRUAs should share benefits from environmental initiatives and attached livelihood components with those most affected. An equilibrium must be negotiated where there are trade-offs between conservation and use of water resources.

- Targeting enabling conditions. CBNRM does not take place in a vacuum. Projects must consider and target enabling conditions in order to achieve sustainable and equitable outcomes.

\section{ETHICS STATEMENT}

Minimal Risk Ethics approval granted on 8th of July 2015 Number: MR/14/15-392 by Research Ethics Office King's College London. Oral consent from interviewees was sought.

\section{AUTHOR CONTRIBUTIONS}

NR has contributed to the paper by choosing the topic, the framework, constructing the argument, and writing, contributing to data collected in the field and by putting the paper together. DS has contributed to the paper with her field data and experience, as well as literature review.

\section{ACKNOWLEDGMENTS}

This research has been undertaken thanks to the support of the Economic and Social Research Council of the United Kingdom, in a CASE partnership with WWF-UK under grant number ES/J500057/1. The authors would like to thank Dr. William Ojwang and other WWF-UK and Kenya colleagues for facilitating the data collection process and providing insights.

Boerema, A., Rebelo, A. J., Bodi, M. B., Esler, K. J., and Meire, P. (2016). Are ecosystem services adequately quantified? J. Appl. Ecol. 54, 358-370. doi: 10.1111/1365-2664.12696

Butler, V. (1998). Controversy in Kenya: unquiet on the western front. Int. Wildl. $28,12-23$.

Cleaver, F. (1999). Paradoxes of participation: questioning participatory approaches to development. J. Int. Dev. 11:597. doi: 10.1002/(SICI)10991328(199906)11:4<597::AID-JID610>3.0.CO;2-Q

Cleaver, F., and Kaare, B. (1998). "Social Embeddedness and Project Practice: A Gendered Analysis of Promotion and Participation in the Hesawa Programme, Tanzania”. University of Bradford for SIDA.

Crook, R., and Manor, J. (1998). Democracy and Decentralization in Southeast Asia and West Africa: Participation, Accountability and Performance. Cambridge: University of Cambridge.

De Groot, R. S., Wilson, M. A., and Boumans, R. M. (2002). A typology for the classification, description and valuation of ecosystem functions, goods and services. Ecol. Econ. 41, 393-408. doi: 10.1016/S0921-8009(02) 00089-7

Dessu, S. B., and Melesse, A. M. (2012). Modelling the rainfall-runoff process of the Mara River basin using the Soil and Water Assessment Tool. Hydrol. Process. 26, 4038-4049. doi: 10.1002/hyp.9205 
Eyburn, R., and Ladbury, S. (1995). "Chapter 17: Popular participation in aid assisted projects: why more in theory than in practicel?", in Power and Participatory Development, eds N. Nelson and R. Wright (London: IT Publications).

Fabricius, C., Folke, C., Cundill, G., and Schultz, L. (2007). Powerless spectators, coping actors, and adaptive co-managers: a synthesis of the role of communities in ecosystem management. Ecol. Soc. 12:art29. doi: 10.5751/ES-02072-120129

Franks, P., Martin, A., and Schreckenberg, K. (2016). From Livelihoods to Equity for Better Protected Area Conservation. Available online at: http://pubs.iied.org/ pdfs/17370IIED.pdf

Gilmour, D. A., and Fisher, R. J. (1991). Villagers, Forests, and Foresters: The Philosophy, Process and Practice of Community Forestry in Nepal. Kathmandu: Sahyogi Press.

GIZ (2018). Deutsche Gesellschaft für Internationale Zusammenarbeit (GIZ). Map of Mara Basin WRUAs.

Hobley, M. (2005). Forest Policy and Environment Programme: Grey Literature Building state-people relationships in forestry, (November), 1-7.

Hoffman, C., Melesse, A. M., and McClain, M. E. (2011). "Geospatial mapping and analysis of water availability, demand, and use within the Mara River Basin," in Nile River Basin, eds A. M. Melesse, W. Abtew, and S. G. Setegn (Cham: Springer), 359-382.

Hoffman, C. M. (2007). Geospatial Mapping and Analysis of Water AvailabilityDemand-Use Within the Mara River Basin. Florida International University.

Hulme, D., and Murphree, M. (1999). Communities, wildlife and "the new conservation" Africa. J. Int. Dev. 11, 277-285. doi: 10.1002/(SICI)10991328(199903/04)11:2<277::AID-JID582>3.0.CO;2-T

Hutton, J., Adams, W. M., and Murombedzi, J. C. (2005). Back to the barriers? Changing narratives in biodiversity conservation. Forum Dev. Stud. 32, 341-370. doi: 10.1080/08039410.2005.9666319

Jere, P., Varela, K., and Voysey, B. (2000). Synthesis Study of Initiatives in Co-Management of Natural Resources in Malawi. Working group on comanagement of forest goods and services. National Forestry Policy, Lilongwe.

Kapoor, I. (2001). Towards participatory environmental management. J. Environ. Manage. 63, 269-279. doi: 10.1006/jema.2001.0478

Kellert, S. R., Mehta, J. N., Ebbin, S. A., and Lichtenfeld, L. L. (2000). Community natural resource management: promise, rhetoric, and reality. Soc. Nat. Resour. 13, 705-715. doi: 10.1080/089419200750035575

Kenya National Bureau of Statistics (2010). The 2009 Kenya Population and Housing Census, Volume II: Population and Household Distribution by SocioEconomic Characteristics. Kenya National Bureau of Statistics.

King, J., Tharme, R. E., and De Villiers, M. (2000). Environmental Flow Assessments for Rivers: Manual for the Building Block Methodology. Water Research Commission Pretoria.

Kumasi, T. C., Obiri-Danso, K., and Ephraim, J. H. (2010). Community engagement in the sustainable management of rivers: barekese catchment, Kumasi, Ghana. Environ. Dev. Sustain. 12, 927-943. doi: 10.1007/s10668-010-9232-1

Little, P. D. (1994). "The link between local participation and improved conservation: a review of issues and experiences," in Natural Connections: Perspectives in Community-Based Conservation, eds D. Western and M. Wright (Washington, DC: Island Press), 347-372.

Lynch, O. J., and Alcorn, J. B. (1994). "Tenurial rights and communitybased conservation," in Natural Connections: Perspectives in Community-Based Conservation, eds D. Western and M. Wright (Washington, DC: Island Press), 373-392.

Mango, L. M., Melesse, A. M., McClain, M. E., Gann, D., and Setegen, S. (2010). Land use and climate change impacts on the hydrology of the upper Mara River Basin, Kenya: results of a modelling study to support better resource management. Hydrol. Earth Syst. Sci. 15, 2245-2258. doi: 10.5194/hess-15-2245-2011

Manzungu, E., and Derman, B. (2016). Surges and ebbs: National politics and international influence in the formulation and implementation of IWRM in Zimbabwe. Water Altern. 9, 493-512.

Mati, B. M., Mutie, S., Gadain, H., Home, P., and Mtalo, F. (2008). Impacts of land-use/cover changes on the hydrology of the transboundary Mara River, Kenya/Tanzania. Lakes Reserv. 13, 169-177. doi: $10.1111 / j .1440-1770.2008 .00367 . x$
Mbaiwa, J. E. (2005). Wildlife resource utilization at Moremi Game Reserve and Khwai community area in the Okavango Delta, Botswana. J. Environ. Manage. 77, 144-156. doi: 10.1016/j.jenvman.2005.03.007

Mehta, J. N., and Kellert, S. R. (1998). Local attitudes toward communitybased conservation policy and programmes in Nepal: a case study in the Makalu-Barun Conservation Area. Environ. Conserv. 25, 320-333. doi: $10.1017 /$ S037689299800040X

Molle, F. (2008). Nirvana concepts, narratives and policy models: insight from the water sector. Water Altern. 1, 131-156.

Oldekop, J. A., Holmes, G., Harris, W. E., and Evans, K. L. (2015). A global assessment of the social and conservation outcomes of protected areas. Conserv. Biol. 30, 133-141. doi: 10.1111/cobi.12568

Ostrom, E. (1990). Governing the Commons: The Evolution of Institutions for Collective Action. Cambridge: Cambridge University Press. doi: $10.1017 /$ СBO9780511807763

Parker, S. (1997). "Annapurna conservation area project: in pursuit of sustainable development?", in Approaches to Sustainable Development, eds R. M. Auty and K. Brown (London: Pinter), 144-168.

Rap, E., and Wester, F. (2013). The practices and politics of making policies: irrigation management transfer in Mexico. Water Altern. 6, 506-531.

Reardon, T., and Vosti, S. A. (1995). Links between rural poverty and the environment in developing countries: asset categories and investment poverty. World Dev. 23, 1495-1506. doi: 10.1016/0305-750X(95)00061-G

Republic of Kenya (2007). Water Resource Management Rules, Laws of Kenya. Government Printer Republic of Kenya.

Reza, N. (2013). Saving Water in the Serengeti: Yale Graduate and Undergraduate Students Collaborate on Water Sustainability in East Africa. Available online at: http://www.yalescientific.org/2013/12/saving-water-in-the-serengeti-yalegraduate-and- undergraduate-students- collaborate-on-water-sustainabilityin-east-africa/

Ribot, J. C. (2002). Democratic Decentralization of Natural Resources: Institutionalizing Popular Participation. Washington, DC: World Resources Institute.

Ribot, J. C. (2003). Democratic decentralization of natural resources: Institutional choice and discretionary power transfers in sub-saharan Africa. Public Administr. Dev. 23, 53-65. doi: 10.1002/pad.259

Rodríguez-Martínez, R. E. (2007). Community involvement in marine protected areas: the case of Puerto Morelos reef, Mexico. J. Environ. Manage. 88, 1151-1160. doi: 10.1016/j.jenvman.2007.06.008

Rusca, M., Schwartz, K., Hadzovic, L., and Ahlers, R. (2015). Adapting generic models through bricolage: elite capture of water users associations in Peri-urban Lilongwe. Eur. J. Dev. Res. 27, 777-792. doi: 10.1057/ejdr. 2014.58

Sarin, M. (1995). Joint forest management in India: achievements and unaddressed challenges. Unasylva 180, 30-36.

Savenije, H. H. G., and Van der Zaag, P. (2008). Integrated water resources management: concepts and issues. Phys. Chem. Earth Parts A/B/C 33, 290-297. doi: $10.1016 /$ j.pce.2008.02.003

Schreckenberg, K., Franks, P., Martin, A., and Lang, B. (2016). Unpacking equity for protected area conservation. PARKS. 22, 11-26, doi: 10.2305/IUCN.CH.2016.PARKS-22-2KS.en

Schultz, L., Duit,A., and Folke C (2011). Participation, adaptive co-management and Management performance in the world of network of biosphere reserves. World Dev. 39, 662-671. doi: 10.1016/j.worlddev.2010.09.014

Shackleton, S., Campbel, B., Wollen Berg, E., and Edmunds, D. (2002). Devolution and Community Based Natural Resource Management: Creating Space for Local People to Participate and Benefit. ODI Programme for Land and Agrarian Studies, London.

Shackleton, S., and Campbell, B. (2001). Devolution in Natural Resource Management: Institutional Arrangements and Power Shifts: A Synthesis of Case Studies From Southern Africa. CIFOR.

Smet, J. (2003). Water User Associations'. Background paper produced for the Management Models Study. The Hague: IRC International Water and Sanitation Centre.

Stoll-Kleemann, S., and Welp, M. (2008). Participatory and integrated management of biosphere reserves - lessons from case studies and a global survey. Gaia 17, 161-168. doi: 10.14512/gaia.17.S1.14 
Strum, S. C. (1994). "Lessons learned," in Natural Connections: Perspectives in Community-Based Conservation, eds D. Western and M. Wright (Washington, DC: Island Press), 512-523.

Suhardiman, D., and Giordano, M. (2014). Is there an alternative for irrigation reform?. World Dev. 57, 91-100. doi: 10.1016/j.worlddev.2013.11.016

Taylor, M. (2001). Whose Agenda? Reassessing the Role of Community-Based Natural Resources Management in Botswana. Mimeo.

Tharme, R. E. (2003). A global perspective on environmental flow assessment: emerging trends in the development and application of environmental flow methodologies for rivers. River Res. Appl. 19, 397-441. doi: 10.1002/rra.736

The Brisbane Declaration (2007). International River symposium, Brisbane, September 2017. Available online at: http://http://riversymposium.com/about/ brisbane-declaration/ (Accessed December 1, 2017).

The Water Act (2002). Government of Kenya, Ministry of Water and Irrigation. Available online at: https://ppp.worldbank.org/public-private-partnership/ sites/ppp.worldbank.org/files/documents/Kenya_water\%20act_EN.pdf (Accessed November 11, 2017).

Treisman, D. (2007). The Architecture of Government: Rethinking Political Decentralization. Cambridge: Cambridge University Press. doi: $10.1017 /$ CBO 9780511619151

Vrebos, D., Staes, J., Vandenbroucke, T., Johnston, R., Muhumuza, M., Kasabeke, C., et al. (2015). Mapping ecosystem service flows with land cover scoring maps for data-scarce regions. Ecosyst. Serv. 13, 28-40. doi: 10.1016/j.ecoser.2014.11.005

Wainwright, C., and Wehrmeyer, W. (1998). Success in integrating conservation and development? A study from Zambia. World Dev. 26, 933-944. doi: 10.1016/S0305-750X(98)00027-8

Wambugu, G. (2017). Social Values of Reserve Flows: Case Study: Mara River Basin, Kenya. MSc thesis, UNESCO-IHE, Delft.
Wangai, P. W., Burkhard, B., and Muller, F. (2016). A review of studies on ecosystem services in Africa. Int. J. Sustain. Built Environ. 5, 225-224. doi: 10.1016/j.ijsbe.2016.08.005

Wanje, N., Michael Nyiro, A., and Nyiro, R. (2017). Drivers of success for community based natural resource projects in Coast Region of Kenya. Int. J. Environ. Sci. Nat. Resour. 3, 1-11. doi: 10.19080/IJESNR.2017.03.555624

Watson, G., Vijay Jagannathan, N., Gelting, R., and Beta, H. (1999). "Water and sanitation associations: review and best practices," in User Organizations for Sustainable Water Services, eds A. Subramanian, N. Vijay Jagannathan, and R. Meinzen-Dick (Washington, DC: The World Bank).

Wells, M., and Brandon, K. (1992). People and Parks: Linking Protected Area Management With Local Communities. Washington, DC: World Bank; WorldWildlife Fund; U.S. Agency for International Development.

Wong, S. (2013). Challenges to the elite exclusion-inclusion dichotomy reconsidering elite capture in community-based natural resource management. South Afr. J. Int. Affairs 20, 379-391. doi: 10.1080/10220461.2013.841800

Zulu, L. C. (2009). Politics of scale and community-based forest management in southern Malawi. Geoforum 40, 686-699. doi: 10.1016/j.geoforum.2009.05.007

Conflict of Interest Statement: The authors declare that the research was conducted in the absence of any commercial or financial relationships that could be construed as a potential conflict of interest.

Copyright $\odot 2018$ Richards and Syallow. This is an open-access article distributed under the terms of the Creative Commons Attribution License (CC BY). The use, distribution or reproduction in other forums is permitted, provided the original author(s) and the copyright owner(s) are credited and that the original publication in this journal is cited, in accordance with accepted academic practice. No use, distribution or reproduction is permitted which does not comply with these terms. 